\title{
Increased Adhesion of Listeria monocytogenes Strains to Abiotic Surfaces under Cold Stress
}

\author{
Bo-Hyung Lee ${ }^{1,2 *}$, Michel Hébraud ${ }^{3}$ and Thierry Bernardi ${ }^{1}$ \\ ${ }^{1}$ Biofilm Control, Biopôle Clermont Limagne, Saint-Beauzire, France, ${ }^{2}$ Université Clermont Auvergne, Clermont-Ferrand, \\ France, ${ }^{3}$ Institut National de la Recherche Agronomique, Université Clermont Auvergne, UMR MEDiS, \\ Saint-Genès-Champanelle, France
}

OPEN ACCESS

Edited by:

Pierina Visciano,

Università di Teramo, Italy

Reviewed by:

Efstathios D. Giaouris,

University of the Aegean, Greece

Even Heir,

Nofima, Norway

*Correspondence:

Bo-Hyung Lee

2bohyung@gmail.com

Specialty section:

This article was submitted to

Food Microbiology,

a section of the journal

Frontiers in Microbiology

Received: 20 August 2017

Accepted: 30 October 2017

Published: 14 November 2017

Citation:

Lee B-H, Hébraud $M$ and Bernardi T

(2017) Increased Adhesion of Listeria monocytogenes Strains to Abiotic

Surfaces under Cold Stress.

Front. Microbiol. 8:2221.

doi: 10.3389/fmicb.2017.02221
Food contamination by Listeria monocytogenes remains a major concern for some food processing chains, particularly for ready-to-eat foods, including processed foods. Bacterial adhesion on both biotic and abiotic surfaces is a source of contamination by pathogens that have become more tolerant or even persistent in food processing environments, including in the presence of adverse conditions such as cold and dehydration. The most distinct challenge that bacteria confront upon entry into food processing environments is the sudden downshift in temperature, and the resulting phenotypic effects are of interest. Crystal violet staining and the BioFilm Ring Test ${ }^{\circledR}$ were applied to assess the adhesion and biofilm formation of 22 listerial strains from different serogroups and origins under cold-stressed and cold-adapted conditions. The physicochemical properties of the bacterial surface were studied using the microbial adhesion to solvent technique. Scanning electron microscopy was performed to visualize cell morphology and biofilm structure. The results showed that adhesion to stainless-steel and polystyrene was increased by cold stress, whereas cold-adapted cells remained primarily in planktonic form. Bacterial cell surfaces exhibited electrondonating properties regardless of incubation temperature and became more hydrophilic as temperature decreased from 37 to $4^{\circ} \mathrm{C}$. Moreover, the adhesion of cells grown at $4^{\circ} \mathrm{C}$ correlated with affinity for ethyl acetate, indicating the role of cell surface properties in adhesion.

Keywords: Listeria monocytogenes, cold stress, adhesion, biofilm, BRT ${ }^{\circledR}$, crystal violet staining, MATS, SEM

\section{INTRODUCTION}

In recent decades, the foodborne pathogen Listeria monocytogenes has become a notable threat to food manufacturers, particularly those making ready-to-eat (RTE) foods (Jofré et al., 2016; Vongkamjan et al., 2016). Infection with this saprophytic and psychrotrophic gram-positive pathogen results in a high mortality rate, especially in susceptible groups such as pregnant women or senior populations (Orsi et al., 2011).

Listeria monocytogenes efficiently survives under extreme conditions, such as $40 \% \mathrm{w} / \mathrm{v} \mathrm{NaCl}$ or pH 3.0 (Liu et al., 2005). The risk of listeriosis has increased with growing consumption of RTE foods or frozen foods requiring minimal heat treatment before consumption because food processing plants often utilize adverse conditions such as refrigeration, high salt concentration, 
or low $\mathrm{pH}$ to preserve foods. Moreover, L. monocytogenes persists by adhering to food contact surfaces, causing the contamination of final food products (Ferreira et al., 2014). A biofilm is a sessile community of bacterial cells embedded in a matrix of selfproduced extracellular polymeric substances (EPS), including proteins, polysaccharides, and extracellular DNA. According to recent studies, the composition of EPS in the L. monocytogenes biofilm matrix is dominated by teichoic acids (Brauge et al., 2016; Colagiorgi et al., 2016). Biofilms are often multi-species in nature, and interactions with other bacteria may benefit biofilm formation by L. monocytogenes (Giaouris et al., 2015). Although maturity may vary depending on environmental conditions, fundamental biofilm growth involves bacterial adhesion to surfaces (Garrett et al., 2008).

Given increasing concerns that biofilms in food premises lead to food contamination with L. monocytogenes, studies have primarily compared the effects of temperature on biofilm formation by growing bacteria at different temperatures, most frequently ranging from 4 to $37^{\circ} \mathrm{C}$, and demonstrated that bacteria survive and form biofilms at low temperatures (Di Bonaventura et al., 2008; Nilsson et al., 2011). In general, total biomass production by $L$. monocytogenes strains is augmented with increased incubation temperature, regardless of the adhesion surface, including hydrophilic stainless-steel coupons and hydrophobic polystyrene culture plates. One study showed that storage of $L$. monocytogenes strains at $-20^{\circ} \mathrm{C}$ for 6 and 24 months increased adhesion and biofilm formation on various surfaces, including polystyrene microtiter plates and stainless-steel (Slama et al., 2012). Given its exceptional adaptive ability to mitigate and survive harsh environments, biofilm formation by L. monocytogenes may be an adaptation response to stress (Tasara and Stephan, 2006). However, direct observation of cold stress-induced biofilm production by L. monocytogenes has not been reported to date.

In this study, a total of 22 L. monocytogenes strains of diverse origins and serogroups were investigated to elucidate the impact of cold on phenotypic changes. Cells acclimatized at 37 and $4^{\circ} \mathrm{C}$ were exposed to cold to evaluate the effects of cold stress on bacterial adhesion and biofilm formation on polystyrene and stainless-steel surfaces using the BioFilm Ring Test ${ }^{\circledR}\left(\right.$ BRT $\left.^{\circledR}\right)$, crystal violet $(\mathrm{CV})$ staining, and scanning electron microscopy (SEM). Furthermore, microbial affinity to solvents (MATS) analysis was performed to assess cell surface physicochemical properties and their relationship to surface adhesion characteristics.

\section{MATERIALS AND METHODS}

\section{Listeria monocytogenes Isolates and Culture Conditions}

A panel of 22 isolates of L. monocytogenes from human listeriosis cases, animals, foods and food-related premises were used in this study (Table 1). All strains were analyzed by the Institut Pasteur (Paris, France) for serogrouping using a multiplex PCR assay (Doumith et al., 2004). Serogroup IVb includes serovars 4b, 4d, and $4 \mathrm{e}$; serogroup IIb includes serovars $1 / 2 \mathrm{~b}, 3 \mathrm{~b}$ and 7 ; serogroup
IIa includes $1 / 2 \mathrm{a}$ and $3 \mathrm{a}$; and serogroup IIc includes serovars $1 / 2 \mathrm{c}$ and $3 c$.

Strains were stored in Brain-Heart Infusion (BHI) broth (Laboratorios Conda, Spain) with $8.3 \%$ glycerol at $-20^{\circ} \mathrm{C}$, and each set of experiments was conducted with freshly recovered isolates on BHI agar (Laboratorios Conda, Spain). Strains were maintained on BHI agar for at least 2 days at $37^{\circ} \mathrm{C}$ by subculturing daily onto a fresh agar plate.

\section{Sample Preparation}

Several colonies were harvested using a sterile inoculating loop, suspended in $20 \mathrm{ml}$ of BHI broth and grown at $37^{\circ} \mathrm{C}$ with shaking at $100 \mathrm{rpm}$ to reach stationary phase. After incubation for $15 \mathrm{~h}$, stationary cells were pelleted by centrifugation at $5,000 \times g$ for $10 \mathrm{~min}$ at room temperature, dispersed in $5 \mathrm{ml}$ of fresh BHI broth by vortexing, and utilized for different experiments. Some cells were incubated at 37 and $4^{\circ} \mathrm{C}$ and were denoted positive control and cold-stressed cells, respectively (Figure 1, box A). A portion of the culture was diluted in $20 \mathrm{ml}$ of BHI medium pre-cooled to $4^{\circ} \mathrm{C}$ to obtain an optical density at $600 \mathrm{~nm}$ $\left(\mathrm{OD}_{600}\right)$ of 0.1 and brought to $4^{\circ} \mathrm{C}$ to grow under shaking at $100 \mathrm{rpm}$ for 4 to 7 days until the cells reached stationary phase. Stationary cells were harvested by centrifugation at $5,000 \times g$ for $10 \mathrm{~min}$ at $4^{\circ} \mathrm{C}$ and suspended by vortexing in fresh pre-cooled BHI broth for use as cold-adapted samples (Figure 1, box B). Some cold-adapted cells were streaked onto $\mathrm{BHI}$ agar with a sterile inoculating loop and incubated at $37^{\circ} \mathrm{C}$ overnight. This culture was then exposed to sudden cold stress as described above and designated cold-stressed cells ${ }^{2}$ (Figure 1, box C).

\section{Viable Cell Counts}

Portions of the positive control (precultured at $37^{\circ} \mathrm{C}$ ) and coldadapted cells (precultured at $4^{\circ} \mathrm{C}$ ) were used to obtain viable cell counts. After measuring $\mathrm{OD}_{600}$ with a spectrophotometer (Biomate3, Thermo Scientific, United States), $50 \mu l$ of culture was transferred to tryptone salt (TS) solution containing $0.1 \% \mathrm{w} / \mathrm{v}$ tryptone (Conda, Spain) and $0.85 \% \mathrm{w} / \mathrm{v} \mathrm{NaCl}$ (Sigma-Aldrich, France) and 10-fold serially diluted in TS solution. From each dilution, $100 \mu \mathrm{l}$ was spread on a $\mathrm{BHI}$ agar plate using sterile glass beads in triplicate. After overnight incubation at $37^{\circ} \mathrm{C}$, colonies were counted to calculate colony forming units (CFU) per ml. Total CFU of 30 to 300 per plate were considered valid data.

Two experiments were performed for each condition.

\section{BRT $^{\circledR}$}

The BRT $^{\circledR}$ assay was performed in a polystyrene 96-well microplate (BRT kit C004, BioFilm Control, France) as described by Chavant et al. (2007).

A freshly prepared culture was measured at $\mathrm{OD}_{600}$ to obtain a final $\mathrm{OD}_{600}$ of 0.5 (approximately $1.2 \times 10^{9} \mathrm{CFU} / \mathrm{ml}$ ) in BHI broth kept at two temperatures: $4^{\circ} \mathrm{C}$ for cold-stressed and cold-adapted conditions, and room temperature for a positive control. A portion of the suspension was used to perform a threefold dilution to obtain an $\mathrm{OD}_{600}$ of 0.17 (approximately $3.8 \times 10^{8} \mathrm{CFU} / \mathrm{ml}$ ). Toner 4 (magnetic beads) was added to 


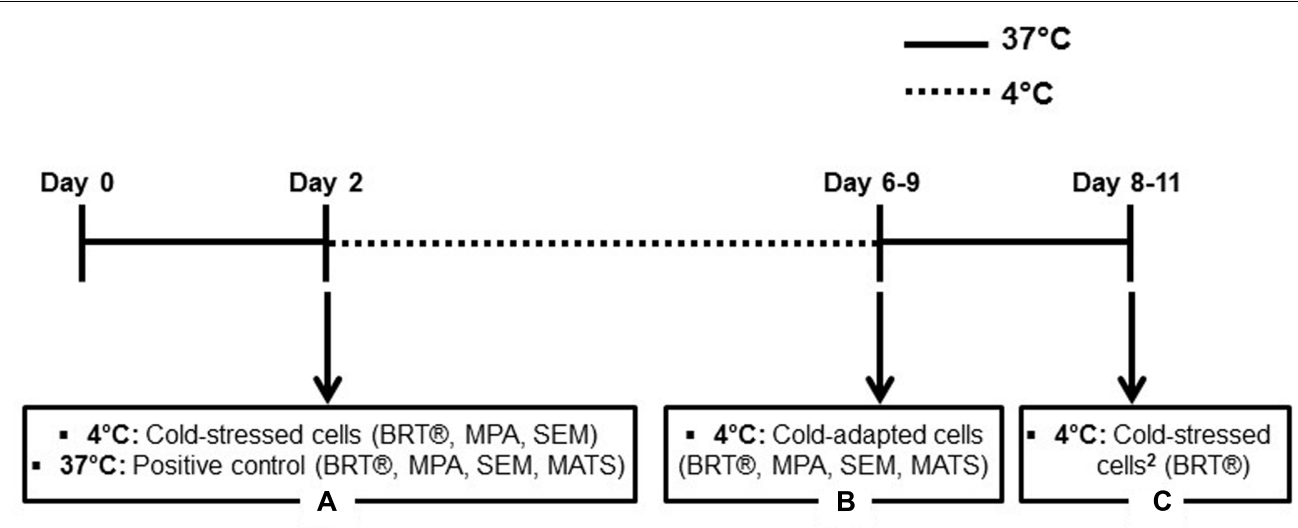

FIGURE 1 | Experimental scheme. Time frame for incubation at 37 or $4^{\circ} \mathrm{C}$ is shown, with arrows indicating cells in stationary phase used for experiments. Each box (A-C) contains the temperatures and names used for sample conditions, with a list of experiments in parentheses.

a final concentration of $10 \mu \mathrm{ml}^{-1}$. After homogenization of these mixtures, $200 \mu \mathrm{l}$ of each bacterial suspension was deposited in each well of the microplate in triplicate. Wells containing only $\mathrm{BHI}$ broth with magnetic beads were added as negative controls.

Microplates were kept static for $24 \mathrm{~h}$ at $4^{\circ} \mathrm{C}$ for cold-stressed (precultured at $37^{\circ} \mathrm{C}$ ) and cold-adapted (precultured at $4^{\circ} \mathrm{C}$ ) conditions and at $37^{\circ} \mathrm{C}$ for the positive control. After incubation, wells were covered with a few drops of Liquid Contrast (inert

TABLE 1 | Listeria monocytogenes strains used in this study.

\begin{tabular}{|c|c|c|c|c|}
\hline Strain & Lineage & Serogroup & Origin & Reference \\
\hline 1 & 1 & $\mathrm{IVb}$ & $\begin{array}{l}\text { Human, epidemic } \\
\text { (pasteurized milk) }\end{array}$ & ScottA \\
\hline 2 & 1 & $\mathrm{IVb}$ & Human, epidemic (hot dog) & \\
\hline 3 & 1 & $\mathrm{IVb}$ & Meat (sausage) & \\
\hline 4 & 1 & $\mathrm{IVb}$ & $\mathrm{FCS}^{\mathrm{a}}$ in $\mathrm{FPE}^{\mathrm{b}}$ & \\
\hline 5 & 1 & $\mathrm{llb}$ & Cow & \\
\hline 6 & 1 & Ilb & Human, sporadic & \\
\hline 7 & 1 & $\mathrm{llb}$ & Chocolate milk, epidemic & \\
\hline 8 & 1 & $\| \mathrm{llb}$ & FCS in FPE & \\
\hline 9 & 1 & $\| \mathrm{lb}$ & Lean meat & \\
\hline 10 & $\|$ & Ila & Not known & \\
\hline 11 & $\|$ & Ila & Cow & \\
\hline 12 & $\|$ & Ila & Hot dog, sporadic & \\
\hline 13 & $\|$ & Ila & Human, sporadic (hot dog) & \\
\hline 14 & $\|$ & Ila & Meat (batter) & \\
\hline 15 & $\|$ & Ila & Meat (sausage) & \\
\hline 16 & $\|$ & Ila & FCS in FPE & \\
\hline 17 & $\|$ & Ila & FCS in FPE & \\
\hline 18 & $\|$ & Ila & Meat (cured ham) & \\
\hline 19 & $\|$ & Ila & Meat (batter) & \\
\hline 20 & $\|$ & $\| \mathrm{l}$ & Rabbit & EGDe \\
\hline 21 & $\|$ & Ilc & FCS in FPE & \\
\hline 22 & $\|$ & Ilc & Human & LO28 \\
\hline
\end{tabular}

aFCS: food contact surface bFP: food processing environment The contaminated food sources of certain epidemic and sporadic cases are specified. and non-toxic oil), and the plates were placed on a magnetic block with 96 mini-magnets centered under the 96 wells of the microplate for $1 \mathrm{~min}$ to apply magnetic fields that attracted mobile beads, creating a quantifiable spot above each minimagnet. The bottoms of the plates were scanned with a plate reader and analyzed using BFC elements $3^{\circledR}$ software (BioFilm Control, France) to obtain a numerical value termed the BioFilm Index (BFI) for each well, which ranged from 0 to 20 depending on the size and intensity of the spot. A BFI of approximately 20 corresponded to high magnetic bead mobility, implying no or very few sessile cells, while a lower BFI or a value of zero resulted from the immobilization of beads by sessile cells.

At least four experiments were performed, with triplicate wells for each condition.

\section{Microtiter Plate Assay (MPA)}

The procedure to prepare a 96-well microplate for microtiter plate assay (MPA) was the same as that described above $\left(\mathrm{BRT}^{\circledR}\right)$, except that no Toner 4 was added. The assay was performed as previously described by Doijad et al. (2015), with slight modifications. After static incubation for $24 \mathrm{~h}$, the absorbance values of negative controls and total cell densities, including sessile and planktonic cells, were measured using a microplate reader (EL800, BioTek, United States) at $\mathrm{OD}_{600}$.

Plates were inverted, and the media and planktonic cells were discarded via gentle tapping. To remove loosely attached bacteria, wells were washed twice with $300 \mu \mathrm{l}$ of sterile saline solution (8.5 $\mathrm{g}$ of $\mathrm{NaCl}$ per 1). Sessile cells were fixed with $300 \mu \mathrm{l}$ of $96 \%$ ethanol (Sigma-Aldrich, France) for $20 \mathrm{~min}$ and air-dried for $2-3 \mathrm{~h}$ at room temperature after removal of the ethanol until no standing moisture was visible. To stain the bacterial biomass, a $0.1 \%$ w/v CV (Merck KGaA, Germany) solution was filtered (0.22- $\mu \mathrm{m}$ filter, Millipore, France), and $220 \mu \mathrm{l}$ was added to each well. After static incubation for $30 \mathrm{~min}$, CV solution was removed by sharply flicking the plates while upside down. Wells were washed three times with $300 \mu \mathrm{l}$ of saline, followed by tapping them upside down on paper towels. Plates were air-dried for 3-4 h, filled with $150 \mu \mathrm{l}$ of $33 \% \mathrm{v} / \mathrm{v}$ acetic acid 
TABLE 2 | Viable cell counts of six strains grown at stationary phase at two temperatures.

\begin{tabular}{lcc}
\hline Strain & $\mathbf{3 7 ^ { \circ } \mathbf { C }}$ & $\mathbf{4}^{\circ} \mathbf{C}$ \\
\hline 1 & $9.36 \pm 0.03$ & $9.46 \pm 0.05$ \\
4 & $9.33 \pm 0.03$ & $9.50 \pm 0.05$ \\
6 & $9.30 \pm 0.03$ & $9.45 \pm 0.03$ \\
11 & $9.27 \pm 0.06$ & $9.43 \pm 0.01$ \\
14 & $9.24 \pm 0.01$ & $9.33 \pm 0.02$ \\
20 & $9.22 \pm 0.04$ & $9.35 \pm 0.20$ \\
\hline
\end{tabular}

Data are presented as the mean log CFU/mI \pm standard deviation at an $\mathrm{OD}_{600}$ of 1 .

(Sigma-Aldrich, France) and placed on a plate shaker with slight agitation for $10 \mathrm{~min}$ to completely destain $\mathrm{CV}$ and obtain a homogenized solution. Destained CV levels were determined using a microplate reader at $\mathrm{OD}_{600}$.

At least four experiments were performed, with triplicate wells for each condition.

\section{Physicochemical Experiments}

The MATS partitioning method (Bellon-Fontaine et al., 1996) was performed to define bacterial cell surface properties. This method involves comparing the affinities of microbial cells for pairs of monopolar and nonpolar solvents, which have similar van der Waals surface tension components. In this study, the following sets of solvents were used: (i) chloroform, an acidic solvent (electron acceptor), and hexadecane, a nonpolar $n$-alkane, and (ii) ethyl acetate, a basic solvent (strong electron donor), and decane, a nonpolar $n$-alkane (Sigma-Aldrich, France).

Cultures grown until stationary phase at 37 and $4^{\circ} \mathrm{C}$ were pelleted by centrifugation at $5,000 \times \mathrm{g}$ for $10 \mathrm{~min}$ at room temperature and $4^{\circ} \mathrm{C}$, respectively. Sterile $0.15 \mathrm{M} \mathrm{NaCl}$ (SigmaAldrich, France) solutions pre-incubated at 37 and $4^{\circ} \mathrm{C}$ were used to wash pellets, in compliance with the original culture temperatures, followed by centrifugation. Bacterial suspensions were prepared to obtain an $\mathrm{OD}$ at $400 \mathrm{~nm}\left(\mathrm{OD}_{400}\right)$ of approximately 0.6 to 0.7 , and the initial $\mathrm{OD}_{400}$ was measured as $\left[\mathrm{A}_{0}\right]$. A suspension in a volume of $2.4 \mathrm{ml}$ was vortexed for $60 \mathrm{~s}$ with $0.4 \mathrm{ml}$ of each solvent in a glass tube. The mixture was allowed to stand static for $15 \mathrm{~min}$ to ensure the complete separation of both phases. The absorbance of the aqueous phase was measured at $\mathrm{OD}_{400}[\mathrm{~A}]$. The percentage of cells in each solvent was calculated using the following equation: percent affinity $=\left[1-\left(\mathrm{A} / \mathrm{A}_{0}\right)\right] \times 100$.

Each experiment was performed in quadruplicate with independently grown bacterial cultures.

\section{SEM}

Biofilms were grown on sterile stainless-steel coupons to visualize adhesion patterns, biofilm architecture, and cell morphologies via SEM with positive control, cold-stressed, and cold-adapted cells.

Fresh cultures in $\mathrm{BHI}$ broth were prepared to obtain an $\mathrm{OD}_{600}$ of 0.5 , and $7 \mathrm{ml}$ of each bacterial suspension was poured into a petri dish (55-mm diameter) containing a sterile stainlesssteel coupon (AISI 304, mean roughness $=0.064$ ) and statically incubated for $24 \mathrm{~h}$ at $37^{\circ} \mathrm{C}$ for a positive control and at $4^{\circ} \mathrm{C}$ for the cold-stressed and cold-adapted conditions. After removing the cultures using a pipette, the coupons were gently washed twice by filling the petri dishes with sterile saline solution to remove nonadherent cells. Sessile cells and biofilms were fixed on each coupon in $10 \mathrm{ml}$ of a solution containing 3\% glutaraldehyde in $0.2 \mathrm{M}$ cacodylate buffer ( $\mathrm{pH} 7.4$ ) in a 50 -ml glass beaker at $4^{\circ} \mathrm{C}$ for a minimum of $1 \mathrm{~h}$ to overnight. Coupons were washed three times for 15 min each via immersion in cacodylate buffer, followed by dehydration using a graded ethanol series (70, 90, and 100\%) three times for $15 \mathrm{~min}$ each. Further dehydration was performed in a 50:50 mixture of ethanol:hexamethyldisilazane (HMDS) three times for $10 \mathrm{~min}$ each. Samples were immersed in pure

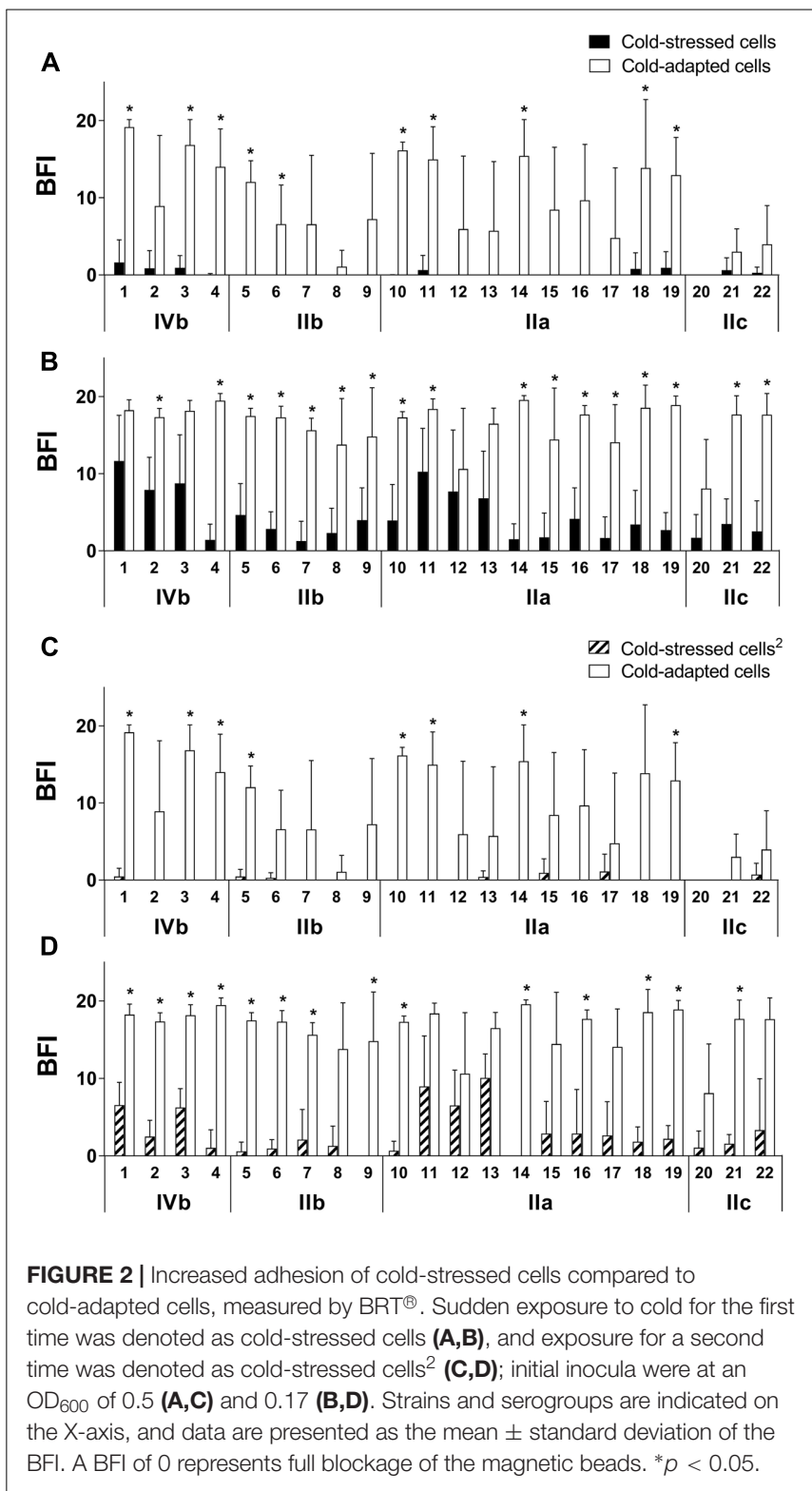


HMDS (Delta Microscopies, France) twice for $10 \mathrm{~min}$, followed by air-drying overnight at room temperature. Coupons were mounted on stubs using adhesive carbon tabs, sputter-coated with gold-palladium (JFC-1300, JEOL, Japan) and observed with a scanning electron microscope (JEOL 6060-LV, JEOL, Japan) at $5 \mathrm{kV}$ in high-vacuum mode.

\section{Statistical Analysis}

A $t$-test was performed on data comparing cold-stressed and cold-adapted cells or positive control and cold-adapted cells to test for statistically significant differences. Correlations were evaluated to identify any effects of cell surface properties on bacterial adhesion and biofilm formation by calculating the Pearson's correlation coefficient. All data were analyzed using Prism 7 software (Graphpad software Inc., United States), and significance was assigned at $p<0.05$.

\section{RESULTS}

\section{Viable Cell Counts}

Six stains composed of four different serogroups with diverse origins were selected for viable cell count tests to verify the relationship between $\mathrm{OD}_{600}$ values and viable cell numbers. As shown in Table 2, the two stationary cultures acclimated to 37 and $4^{\circ} \mathrm{C}$ resulted in comparable numbers of viable cells, with no significant differences.

\section{Evaluation of Adhesion and Biofilm Formation on a Polystyrene Surface $\mathrm{BRT}^{\circledR}$}

The ability of 22 L. monocytogenes strains to adhere to an abiotic surface was analyzed using BRT ${ }^{\circledR}$. BFI, with a value ranging from 20 to 0 , is associated with the extent of blockage of magnetic beads (Toner 4) by sessile bacterial cells at the bottom of polystyrene microplate wells. Therefore, differences in BFI are caused by varying abilities to adhere. All strains exhibited higher adhesion ability when exposed to cold shock by demonstrating lower BFI scores (Figure 2). Statistical differences $(p<0.05)$ in BFI values between cold-stressed and cold-adapted cells were observed for 19 strains in either of the two inocula (Figures 2A,B). Further tests were performed to verify whether this adhesion phenomenon was reversible. Cold-adapted cells were cultured at $37^{\circ} \mathrm{C}$ and re-exposed to a sudden temperature downshift (coldstressed cells ${ }^{2}$ ). Interestingly, the same response was observed for adhesion profiles (Figures 2C,D). No significant difference was observed for any strain between cells that were exposed to sudden cold shock for the first time (cold-stressed cells) and the second time (cold-stressed cells ${ }^{2}$ ), demonstrating that enhanced adhesion upon cold exposure represents a transient phenotype switch (Supplementary Figure 1).

When positive control cells were incubated at $37^{\circ} \mathrm{C}$, all strains completely blocked the beads, resulting in a BFI of 0 for all inocula (data not shown).

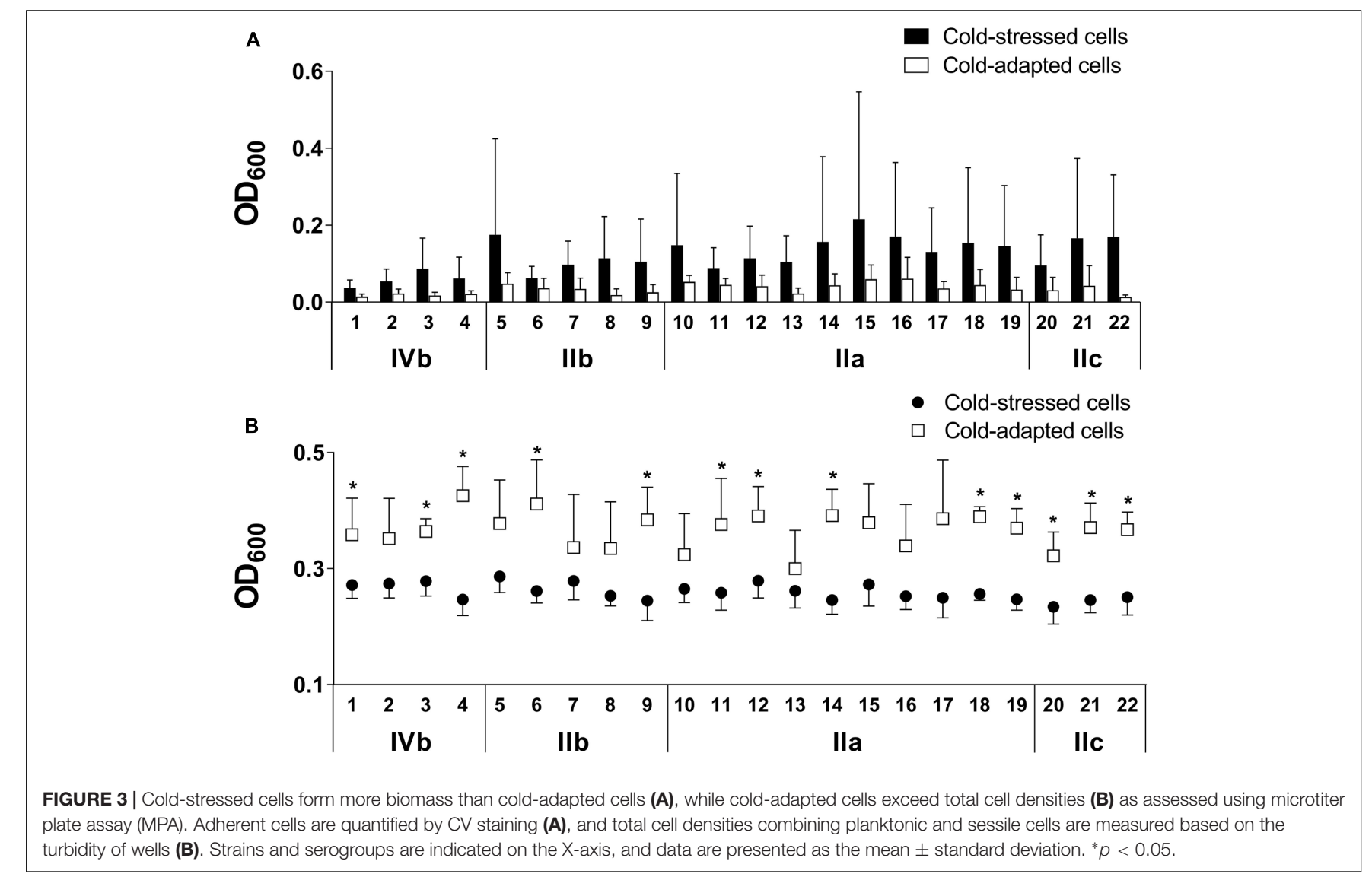




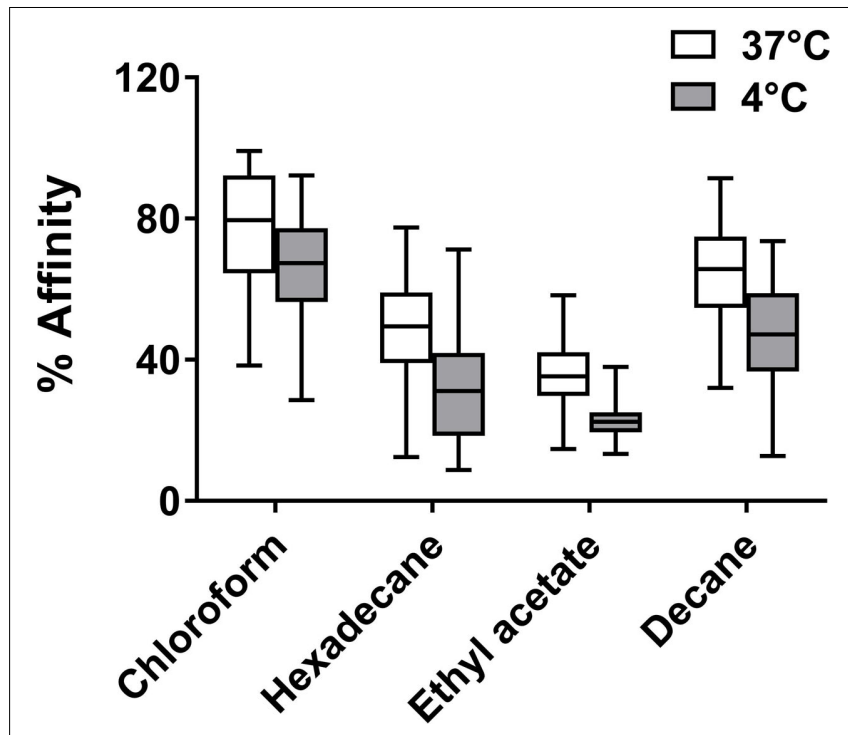

FIGURE 4 | Solvent affinities (\%) of all 22 Listeria monocytogenes strains in stationary phase at 37 and $4^{\circ} \mathrm{C}$. Box plot whiskers indicate minimum and maximum values, and the line in the middle of the box is plotted at the median. The affinity for each solvent under two temperatures differs significantly $(p<0.01)$.

\section{MPA}

Microtiter plate assay was performed to assess sessile biomasses and total cell densities after incubation for $24 \mathrm{~h}$ at $4^{\circ} \mathrm{C}$ for coldstressed and cold-adapted conditions and at $37^{\circ} \mathrm{C}$ for positive control. Much greater biomass quantities were obtained by $\mathrm{CV}$ staining for the positive control than for cold-stressed or coldadapted cells (Supplementary Figure 2).

Cold-adapted cells showed overall higher total cell densities than cold-stressed cells; 13 of the 22 strains were statistically significant $(p<0.05$, Figure 3B). Cold-stressed cells, however, resulted in more sessile bacterial communities than cold-adapted cells (no significance found) as quantified by $\mathrm{CV}$ staining (Figure 3A). The higher total cell densities obtained for coldadapted cells were primarily attributable to planktonic cells. Based on these findings, increased cell numbers in cultures did not result in bacterial adhesion, indicating that enhanced adhesion is a distinct feature of cold-stressed cells.

\section{Cell Surface Physicochemical Properties}

Positive control and cold-adapted cells, grown at 37 and $4^{\circ} \mathrm{C}$ until stationary phase, respectively, were prepared for the MATS test to compare the surface physicochemical properties of cells that acclimated to different temperatures. The MATS results obtained for all $22 \mathrm{~L}$. monocytogenes grown at 37 and $4^{\circ} \mathrm{C}$ until stationary phase in BHI media are shown in Supplementary Figure 3.

As shown in Figure 4, the general affinity of the 22 L. monocytogenes for chloroform (an electron-acceptor solvent) was higher than the affinity for hexadecane (a non-polar solvent), regardless of the culture temperature, indicating the strong electron donor nature of these bacteria. Likewise, bacterial affinity for ethyl acetate (an electron-donating solvent) was lower than

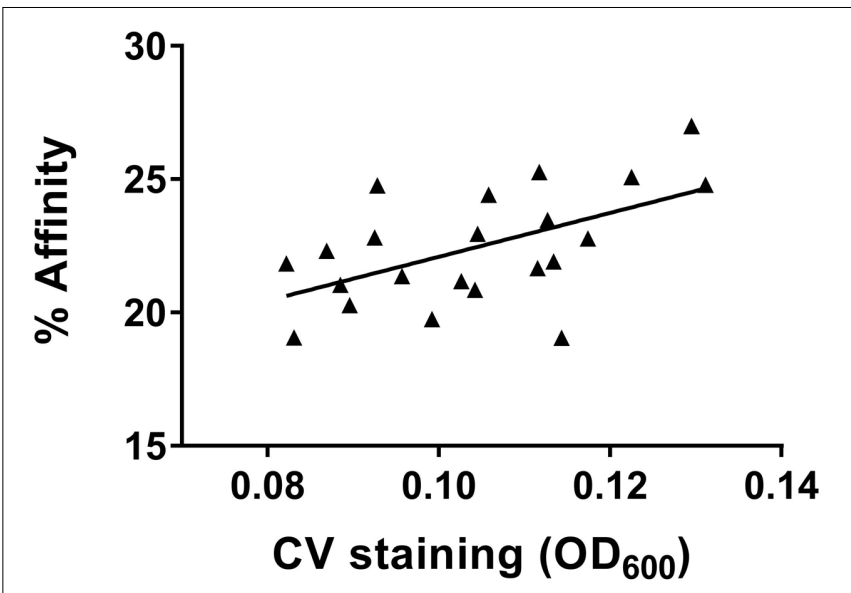

FIGURE 5 | Correlation $\left(r^{2}=0.3055, p<0.01\right)$ between affinity for ethyl acetate and quantification of adherent cells, measured by $\mathrm{CV}$ staining of cold-adapted cells.

for decane (a nonpolar solvent), indicating that the electronaccepting nature of the bacteria grown at either temperature was weak. Affinity for hexadecane decreased from $49 \pm 14 \%$ at $37^{\circ} \mathrm{C}$ to $32 \pm 15 \%$ at $4^{\circ} \mathrm{C}(p<0.01)$, demonstrating that cell surfaces became relatively more hydrophilic as cells adapted to cold temperature.

Relationships between the affinities for the four solvents and adhesion data obtained via two methods, CV staining and BRT, were evaluated using Pearson's correlation coefficient $\left(r^{2}\right)$. A positive correlation was identified between the adhesion results obtained from CV staining and the affinity for ethyl acetate obtained from the MATS test for cold-adapted cells grown at $4^{\circ} \mathrm{C}$ $\left(r^{2}=0.3055, p<0.01\right)$ (Figure 5).

\section{SEM Observation}

Scanning electron microscopy images of cells grown under all three tested conditions (positive control, cold-stressed, and coldadapted cells) were obtained to analyze surface colonization patterns and biofilm structures as well as the morphologies of individual cells. Low to high magnifications were applied over several zones. There was greater variance in the maturity of biofilms among strains grown under positive control conditions (Figure 6, left column), showing that the biofilmforming capability of $L$. monocytogenes is strain-dependent. Conversely, under cold-stressed and cold-adapted conditions, the variance among strains was less obvious, primarily because no homogeneous mature biofilms were produced. However, coldstressed cells underwent surface colonization with cell aggregates (arrowhead) resulting from sessile cell division (Figure 6, middle column), while analysis of cold-adapted cells revealed the attachment of individual cells in the absence of noticeable cell clusters (Figure 6, right column). Extracellular matrix was observed at high magnification (X 9,000 and higher) among individual cells and between cells and the stainless-steel surface (Figure 7, red circle). Irregular cell sizes were observed under all conditions, but significant cell elongation was more 


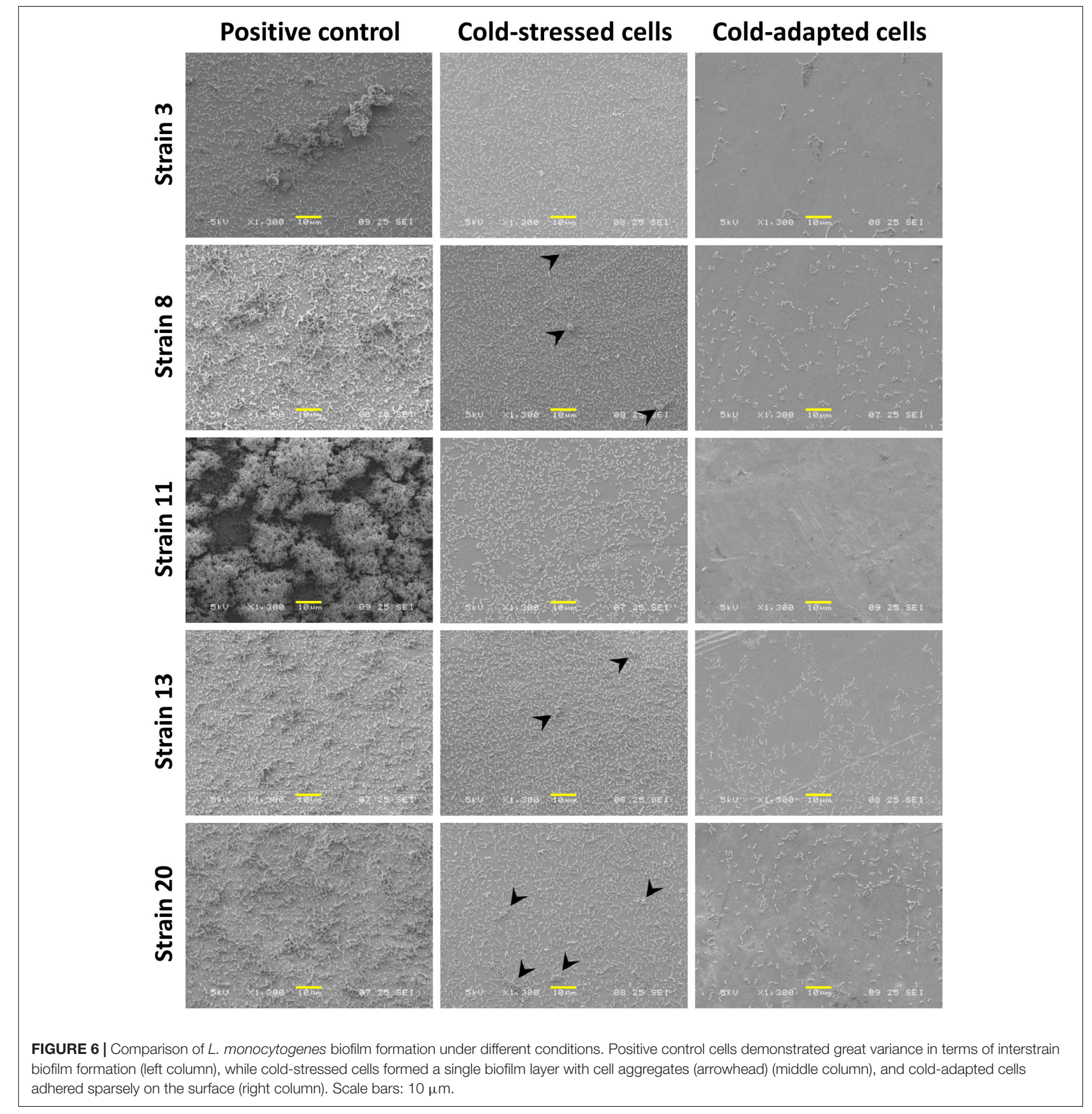

frequently noted among cold-stressed and cold-adapted cells (Figure 7, arrow). This result may be because positive control cells formed more complex biofilm structures that limited the distinction of individual cell morphologies. Similar to a previous report by Harvey et al., spatial colonization was observed, constituting a network of microcolonies (Figures 7E,I) (Harvey et al., 2007). Cells were often found in indented substrate surfaces resulting from scratches on the coupons (Figure 7 , arrowhead).

\section{DISCUSSION}

Certain bacteria adapt to inhabit environments by assuming different forms that are favorable to survival, such as planktonic cells, sessile biofilm communities or spore formation. Biofilms of L. monocytogenes in food processing environments are of great concern for food contamination. L. monocytogenes adapts to the harsh environments employed by food processing facilities, such as antibacterial agents or refrigeration, and reports have 

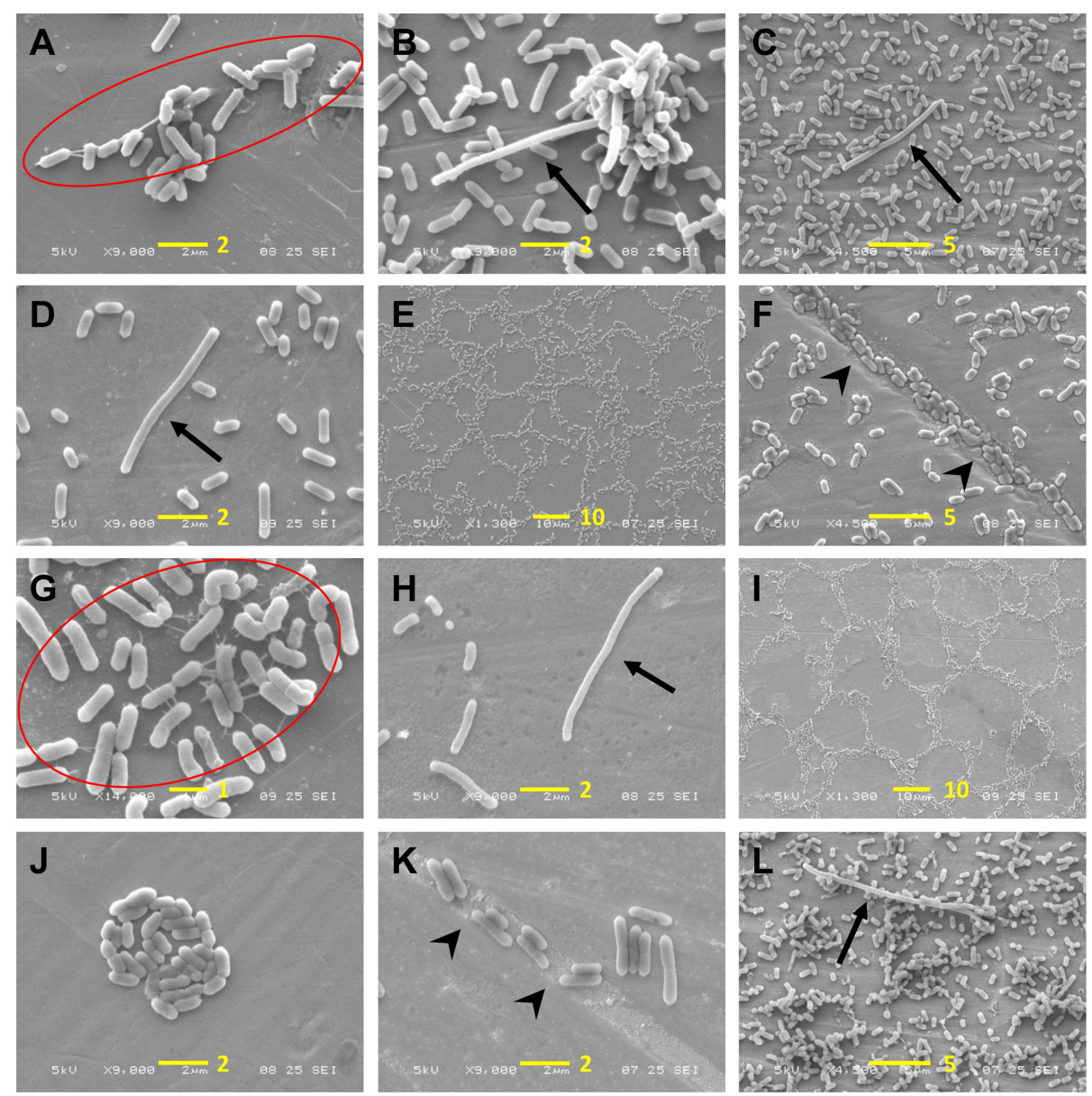

FIGURE 7 | Observation of L. monocytogenes adhesion patterns and cellular morphology. (A-F) Cold-stressed cells; (G-K) cold-adapted cells; (L) positive control cells. EPS are marked in red circles, arrows indicate elongated cells and arrowheads indicate cells in crevices. A scale bar (length in $\mu \mathrm{m}$ ) is indicated in yellow in each figure.

demonstrated that exposing bacteria to sublethal stress leads to cross-protection or cross-adaptation to various stresses and lethal factors (Lou and Yousef, 1997; Lundén et al., 2003). Biofilm production by L. monocytogenes is stimulated to protect against various stressful conditions, making bacterial elimination a serious challenge at food processing facilities (Giaouris et al., 2014).

Significant variation in biofilm production under various conditions was observed for one L. monocytogenes strain, indicating that intra-strain phenotype changes are dependent on experimental settings (Nowak et al., 2015). Moreover, the interstrain variability of biofilm formation has been extensively studied with a focus on its relationships to serogroups or persistence in the food industry. However, a study employing 143 L. monocytogenes strains indicated that experimental settings such as temperature and culture media affect the comprehension of biofilm formation and its relationship to serotype or origin (Kadam et al., 2013). Recently, a study of 98 L. monocytogenes strains revealed no correlation between serological groups and biofilm production (Doijad et al., 2015).
Numerous methods and devices have been developed to detect or quantify biofilms, including staining-based quantification methods, visual identification by microscopy, viable and culturable cell counts, and devices to test bacterial adhesion (Azeredo et al., 2017). BRT ${ }^{\circledast}$ is a microbial adhesion test that is primarily used to assess the simultaneous phenotype switch from planktonic cells into sessile cells. In $\mathrm{BRT}^{\circledR}$, microorganisms are added to microplate wells in planktonic form, some of which adhere to the bottoms of the wells during incubation and switch to a sessile form that hinders the magnetic beads attracted to the magnetic block. Results vary with experimental conditions that affect the process, including planktonic cell growth and adhesion to polystyrene microplates, as well as sessile cell growth. Recently, a new approach to $\mathrm{BRT}^{\circledR}$, designated $\mathrm{cBRT}^{\circledR}$, was developed using serial 10 -fold dilutions of bacterial suspensions to better discriminate biofilm-forming abilities among strains (Di Domenico et al., 2016). However, in the current study, all 22 L. monocytogenes strains revealed homogenous adhesion behavior that was not discernible by $\mathrm{cBRT}^{\oplus}$ under the same experimental conditions, i.e., cold-adapted or cold-stressed 
conditions or incubation at $37^{\circ} \mathrm{C}$. Nevertheless, cBRT ${ }^{\circledR}$ was sensitive for discriminating between cold-stressed and coldadapted cells in terms of bacterial adhesion.

Cells undergo cold shock when subjected to a sudden downshift in temperature. Such a rapid environmental change induces modifications in bacterial cell surface proteins and lipid composition to maintain membrane fluidity homeostasis, which presumably facilitates adhesion as an adaptation strategy against adverse conditions. This behavior may be advantageous for bacterial survival in FPEs where cells might be exposed to sudden cold shock. The current study employed preculture temperatures of 37 and $4^{\circ} \mathrm{C}$ to compare differences in adhesion characteristics upon further exposure to $4^{\circ} \mathrm{C}$. BRT ${ }^{\circledR}$ and MPA results revealed that cold-stressed cells (precultured at $37^{\circ} \mathrm{C}$ ) are more efficient at forming biofilms, while cold-adapted cells (precultured at $4^{\circ} \mathrm{C}$ ) favor growth in the planktonic state. L. monocytogenes cells entering the food processing chain are exposed to temperature downshifts, such as ambient temperature in outdoor food materials or optimal temperature in infected animals to refrigeration temperatures used during food processing or storage. When introduced to the food processing chain, L. monocytogenes adhesion to food contact surfaces is potentially fortified by cold shock, which will increase the chance of food product contamination. Once adapted to the cold, the bacteria in final food products will proliferate to hazardous levels during distribution and storage.

The heterogeneity of a population contributes to the adaptation of L. monocytogenes to sublethal conditions, accompanied by phenotypic and genetic changes (Abee et al., 2016). When cold-adapted cells were returned to $37^{\circ} \mathrm{C}$ and reexposed to cold, they exhibited the same enhanced adhesion, which was indistinguishable by BRT ${ }^{\circledR}$ (Supplementary Figure 1), demonstrating that this transient trait was reacquired when cold stress was removed.

All 22 strains retained basic (electron-donating) properties (a higher affinity for chloroform than hexadecane), regardless of growth temperature, and became more hydrophilic with decreased temperature, as previously described (Chavant et al., 2002). The adhesion data obtained from CV staining of all 22 L. monocytogenes correlated best with cell affinity for ethyl acetate under cold-adapted conditions (Figure 5). This finding aligned with that of Briandet et al., who observed a linear correlation between listerial adhesion to stainless-steel and an affinity for ethyl acetate at different temperatures $\left(37,20,15\right.$, and $\left.8^{\circ} \mathrm{C}\right)$ in the presence of $\mathrm{NaCl}$ (Briandet et al., 1999). Physicochemical properties, including the hydrophobicity of bacterial cells versus that of a substratum, affect the interfacial interactions involved in bacterial attachment to abiotic surfaces. Nonetheless, this trait is negligible in the context of building a mature biofilm structure that is highly dependent on bacterial growth kinetics and EPS production, thus explaining the absence of an obvious relationship between cellular surface properties and biofilm formation at $37^{\circ} \mathrm{C}$ in the current study and in the literature (Cunliffe et al., 1999; Chmielewski and Frank, 2003).

Scanning electron microscopy observations supported the quantitative results obtained with $\mathrm{CV}$ staining and $\mathrm{BRT}^{\circledR}$. Figure 6 shows variable biofilm maturity among the strains. This variability may be attributable to differential biofilm production capabilities, although divergent biofilm kinetics among strains are unable to be excluded. Some strains may have already begun to disperse, while others were still in the process of structuring mature biofilms. SEM observation confirmed the higher bacterial adhesion of cold-stressed cells, along with the formation of cellular aggregates, while cold-adapted cells were only able to form a single sparse layer of adherent cells. This finding aligns with the $\mathrm{BRT}^{\circledR}$ results, demonstrating that $\mathrm{BRT}^{\circledR}$ is applicable for testing the early step of biofilm formation. Moreover, our observations of cells that densely accumulated in the crevices and scratches of stainless-steel surfaces strongly support the thorough cleaning of food contact surfaces to eliminate bacteria, although this may also further damage surfaces and create additional niches for bacterial adhesion.

In the current study, enhanced adhesion of sudden coldstressed L. monocytogenes cells was observed for the first time. $\mathrm{CV}$ staining and SEM observation revealed that L. monocytogenes possesses dramatic interstrain variances in biofilm production, independent of origin or serotype. BRT ${ }^{\circledR}$ is shown to be a sensitive tool to discern the first layer of biofilm formation, facilitating the detection of increased adhesion of cold-stressed cells in the current study. Interestingly, the adhesion of cold-adapted cells correlated with an affinity for ethyl acetate. Further study of cold-stressed cells during cross-adaptation to other stress factors, such as dehydration or antimicrobial agents, will add to our understanding of the behavior of L. monocytogenes in the food processing industry.

\section{AUTHOR CONTRIBUTIONS}

B-HL conceived, designed, and conducted experiments, analyzed the results, and drafted the manuscript. All authors contributed to the experimental design and reviewed and approved the final manuscript.

\section{FUNDING}

This project received funding from the European Union's Horizon 2020 research and innovation program under Marie Skłodowska-Curie grant agreement $N^{\circ} 641984$.

\section{ACKNOWLEDGMENTS}

Our thanks to Brigitte Gaillard-Martinie for SEM sample preparation at INRA, Saint-Genès-Champanelle, and Christelle Blavignac for her assistance with SEM technologies at the Centre Imagerie Cellulaire Santé (Université Clermont Auvergne).

\section{SUPPLEMENTARY MATERIAL}

The Supplementary Material for this article can be found online at: https://www.frontiersin.org/articles/10.3389/fmicb. 2017.02221/full\#supplementary-material 


\section{REFERENCES}

Abee, T., Koomen, J., Metselaar, K. I., Zwietering, M. H., and den Besten, H. M. W. (2016). Impact of pathogen population heterogeneity and stressresistant variants on food safety. Annu. Rev. Food Sci. Technol. 7, 439-456. doi: 10.1146/annurev-food-041715-033128

Azeredo, J., Azevedo, N. F., Briandet, R., Cerca, N., Coenye, T., Costa, A. R., et al. (2017). Critical review on biofilm methods. Crit. Rev. Microbiol. 43, 313-351. doi: 10.1080/1040841X.2016.1208146

Bellon-Fontaine, M.-N., Rault, J., and van Oss, C. J. (1996). Microbial adhesion to solvents: a novel method to determine the electron-donor/electron-acceptor or Lewis acid-base properties of microbial cells. Colloids Surf. B Biointerfaces 7, 47-53. doi: 10.1016/0927-7765(96)01272-6

Brauge, T., Sadovskaya, I., Faille, C., Benezech, T., Maes, E., Guerardel, Y. et al. (2016). Teichoic acid is the major polysaccharide present in the Listeria monocytogenes biofilm matrix. FEMS Microbiol. Lett. 363:fnv229. doi: 10.1093/ femsle/fnv229

Briandet, R., Meylheuc, T., Maher, C., and Bellon-Fontaine, M. N. (1999). Listeria monocytogenes Scott A: cell surface charge, hydrophobicity, and electron donor and acceptor characteristics under different environmental growth conditions. Appl. Environ. Microbiol. 65, 5328-5333.

Chavant, P., Gaillard-Martinie, B., Talon, R., Hébraud, M., and Bernardi, T. (2007). A new device for rapid evaluation of biofilm formation potential by bacteria. J. Microbiol. Methods 68, 605-612. doi: 10.1016/j.mimet.2006. 11.010

Chavant, P., Martinie, B., Meylheuc, T., Bellon-Fontaine, M.-N., and Hebraud, M. (2002). Listeria monocytogenes LO28: surface physicochemical properties and ability to form biofilms at different temperatures and growth phases. Appl. Environ. Microbiol. 68, 728-737. doi: 10.1128/AEM.68.2.728-737.2002

Chmielewski, R. A. N., and Frank, J. F. (2003). Biofilm formation and control in food processing facilities. Compr. Rev. Food Sci. Food Saf. 2, 22-32. doi: 10.1111/j.1541-4337.2003.tb00012.x

Colagiorgi, A., Di Ciccio, P., Zanardi, E., Ghidini, S., and Ianieri, A. (2016). A look inside the Listeria monocytogenes biofilms extracellular matrix. Microorganisms 4:22. doi: 10.3390/microorganisms 4030022

Cunliffe, D., Smart, C. A., Alexander, C., and Vulfson, E. N. (1999). Bacterial adhesion at synthetic surfaces. Appl. Environ. Microbiol. 65, 4995-5002.

Di Bonaventura, G., Piccolomini, R., Paludi, D., D’Orio, V., Vergara, A., Conter, M., et al. (2008). Influence of temperature on biofilm formation by Listeria monocytogenes on various food-contact surfaces: relationship with motility and cell surface hydrophobicity. J. Appl. Microbiol. 104, 1552-1561. doi: 10.1111/j. 1365-2672.2007.03688.x

Di Domenico, E. G., Toma, L., Provot, C., Ascenzioni, F., Sperduti, I., Prignano, G., et al. (2016). Development of an in vitro assay, based on the biofilm ring test ${ }^{\circledR}$, for rapid profiling of biofilm-growing bacteria. Front. Microbiol. 7:1429. doi: $10.3389 /$ fmicb.2016.01429

Doijad, S. P., Barbuddhe, S. B., Garg, S., Poharkar, K. V., Kalorey, D. R., Kurkure, N. V., et al. (2015). Biofilm-forming abilities of Listeria monocytogenes serotypes isolated from different sources. PLOS ONE 10:e0137046. doi: 10.1371/journal. pone. 0137046

Doumith, M., Buchrieser, C., Glaser, P., Jacquet, C., and Martin, P. (2004). Differentiation of the major Listeria monocytogenes serovars by multiplex PCR. J. Clin. Microbiol. 42, 3819-3822. doi: 10.1128/JCM.42.8.3819-3822.2004

Ferreira, V., Wiedmann, M., Teixeira, P., and Stasiewicz, M. J. (2014). Listeria monocytogenes persistence in food-associated environments: epidemiology, strain characteristics, and implications for public health. J. Food Prot. 77, 150-170. doi: 10.1128/JCM.42.8.3819-3822.2004

Garrett, T. R., Bhakoo, M., and Zhang, Z. (2008). Bacterial adhesion and biofilms on surfaces. Prog. Nat. Sci. 18, 1049-1056. doi: 10.1016/j.pnsc.2008. 04.001

Giaouris, E., Heir, E., Desvaux, M., Hébraud, M., Møretrø, T., Langsrud, S., et al. (2015). Intra- and inter-species interactions within biofilms of important foodborne bacterial pathogens. Front. Microbiol. 6:841. doi: 10.3389/fmicb. 2015.00841
Giaouris, E., Heir, E., Hébraud, M., Chorianopoulos, N., Langsrud, S., Møretrø, T., et al. (2014). Attachment and biofilm formation by foodborne bacteria in meat processing environments: causes, implications, role of bacterial interactions and control by alternative novel methods. Meat Sci. 97, 298-309. doi: 10.1016/j. meatsci.2013.05.023

Harvey, J., Keenan, K. P., and Gilmour, A. (2007). Assessing biofilm formation by Listeria monocytogenes strains. Food Microbiol. 24, 380-392. doi: 10.1016/j.fm. 2006.06.006

Jofré, A., Garriga, M., Aymerich, T., Pérez-Rodríguez, F., Valero, A., Carrasco, E., et al. (2016). Closing gaps for performing a risk assessment on Listeria monocytogenes in ready-to-eat (RTE) foods: activity 1 , an extensive literature search and study selection with data extraction on L. monocytogenes in a wide range of RTE food. EFSA Support. Publ. 13:E1141. doi: 10.2903/sp.efsa.2016. EN-1141

Kadam, S. R., den Besten, H. M. W., van der Veen, S., Zwietering, M. H., Moezelaar, R., and Abee, T. (2013). Diversity assessment of Listeria monocytogenes biofilm formation: impact of growth condition, serotype and strain origin. Int. J. Food Microbiol. 165, 259-264. doi: 10.1016/j.ijfoodmicro. 2013.05.025

Liu, D., Lawrence, M. L., Ainsworth, A. J., and Austin, F. W. (2005). Comparative assessment of acid, alkali and salt tolerance in Listeria monocytogenes virulent and avirulent strains. FEMS Microbiol. Lett. 243, 373-378. doi: 10.1016/j.femsle. 2004.12.025

Lou, Y., and Yousef, A. E. (1997). Adaptation to sublethal environmental stresses protects Listeria monocytogenes against lethal preservation factors. Appl. Environ. Microbiol. 63, 1252-1255.

Lundén, J., Autio, T., Markkula, A., Hellström, S., and Korkeala, H. (2003). Adaptive and cross-adaptive responses of persistent and non-persistent Listeria monocytogenes strains to disinfectants. Int. J. Food Microbiol. 82, 265-272. doi: 10.1016/s0168-1605(02)00312-4

Nilsson, R. E., Ross, T., and Bowman, J. P. (2011). Variability in biofilm production by Listeria monocytogenes correlated to strain origin and growth conditions. Int. J. Food Microbiol. 150, 14-24. doi: 10.1016/j.ijfoodmicro.2011. 07.012

Nowak, J., Cruz, C. D., Palmer, J., Fletcher, G. C., and Flint, S. (2015). Biofilm formation of the L. monocytogenes strain 15G01 is influenced by changes in environmental conditions. J. Microbiol. Methods 119, 189-195. doi: 10.1016/j. mimet.2015.10.022

Orsi, R. H., den Bakker, H. C., and Wiedmann, M. (2011). Listeria monocytogenes lineages: genomics, evolution, ecology, and phenotypic characteristics. Int. J. Med. Microbiol. 301, 79-96. doi: 10.1016/j.ijmm.2010. 05.002

Slama, R. B., Bekir, K., Miladi, H., Noumi, A., and Bakhrouf, A. (2012). Adhesive ability and biofilm metabolic activity of Listeria monocytogenes strains before and after cold stress. Afr. J. Biotechnol. 11, 12475-12482. doi: 10.5897/AJB11. 3939

Tasara, T., and Stephan, R. (2006). Cold stress tolerance of Listeria monocytogenes: a review of molecular adaptive mechanisms and food safety implications. J. Food Prot. 69, 1473-1484. doi: 10.4315/0362-028x-69.6.1473

Vongkamjan, K., Fuangpaiboon, J., Turner, M. P., and Vuddhakul, V. (2016). Various ready-to-eat products from retail stores linked to occurrence of diverse Listeria monocytogenes and Listeria spp. Isolates. J. Food Prot. 79, 239-245. doi: 10.4315/0362-028X.JFP-15-361

Conflict of Interest Statement: The authors declare that the research was conducted in the absence of any commercial or financial relationships that could be construed as a potential conflict of interest.

Copyright (C) 2017 Lee, Hébraud and Bernardi. This is an open-access article distributed under the terms of the Creative Commons Attribution License (CC BY). The use, distribution or reproduction in other forums is permitted, provided the original author(s) or licensor are credited and that the original publication in this journal is cited, in accordance with accepted academic practice. No use, distribution or reproduction is permitted which does not comply with these terms. 